\title{
Jammu \& Kashmir's repeated reaffirmed faith in the democratic setup of India: A Study of the State's Public Participation in the General Elections of India (1967-2014)
}

\author{
Ramesh Pandita \\ Assistant Librarian, BGSB University, Rajouri, Jammu \& Kashmir, India \\ R/o 274-C, Durga Nagar Sect. No I, P/o Roop Nagar, Jammu - 180013 \\ E-mail address: rameshpandita90@gmail.com
}

Keywords: Jammu \& Kashmir; India; Parliamentary Elections; Democracy; Secessionist Movement

\begin{abstract}
Purpose: - The up-rise of social unrest in the state of Jammu \& Kashmir (the federal constituent of the Union of India) towards the end of the 20th century with the demand to secede from the union of India has somewhere earned the Jammu \& Kashmir as a conflict zone in the South Asia. The present study has been conceived to examine the public participation of the Jammu \& Kashmir state in the democratic process of the country, by participating in the general elections of India (A referendum or plebiscite of its own kind, whereby people of the state, time and again have reaffirmed their faith in the democratic process of the country) since its accession with the union of India. Some of the aspects evaluated in the present study include, electoral participation, participation of national and local level political parties, participation and performance of national level political parties, representation given to women candidates, etc.
\end{abstract}

Scope: - The study is confined to the state of Jammu \& Kashmir, India and the findings have direct bearing with the state, which has altogether a different geopolitical setup, where public interests stand safeguarded by the constitution of India under article 370 . There is every need to observe caution, while generalizing the findings of the study.

Methodology/Approach: - The study is empirical in nature, undertaken on the secondary data, retrieved from the official website of the Election Commission of India on August 02, 2014.

Findings: - The state of Jammu and Kashmir has so far undergone through 12 general elections in the country. The average voter turnout during these elections from the state remained about $46.76 \%$. At gender level the average voter turnout percentage among males remained $60 \%$ \& for females $39.90 \%$, which compared to voter turnout at national level during the same period at gender level remained $62.39 \%$ and $55.45 \%$ respectively. The voter turnout percentage from the state remained far better than various other states of the country for the same period. The threat perception to not to participate in the electoral process of the country that prevailed over state populace post 1989 got reflected in the subsequent 7 general elections held in the state, especially among female folk, resulting decline in their turnout percentage, when compared to their male counterparts.

Social Implications: - The study is an eye opener to the public at large and to those, who are abetting the Jammu \& Kashmir's secession movement by crying that the state is devoid of democracy. The secession movement which is being backed by the money $\&$ the munitions questions its own credibility \& justification.

\section{INTRODUCTION}

Democracy ensures \& guarantees of securing \& protecting the interests of its subjects by political means. Even, it won't be inappropriate to say that democracy is a form of governance, which provides a climate whereby the people are able to enjoy their fundamental rights to their optimum, have complete freedom of expression, practice religion freely and fearlessly, live their cultural and social practices, actively indulge in socioeconomic activities of their country, have right to lead a wholesome and fulfilling life \& upholding the democratic process of the country by 
participating in its electoral process. Also, there is no denying in the fact that if there is social unrest anywhere in the world or for that matter is being rated as a conflict-zone, it is either for establishing democracy or against the movement active in destabilize the democracy. Still more, if the region is conflict zone and the problem does not pertain to either of the democratic issues, then surely the problem is for different reasons and needs to be addressed accordingly.

The Union of India is one of the largest democracy in the world. The people enjoy and participate in the democratic process of the country at all levels. The union of India comprises of 36 states and union territories and the Jammu \& Kashmir state is one the federal constituents of the democratic structure of the India. The social unrest in the state of Jammu \& Kashmir in general and Kashmir valley in particular is not clandestine to anybody, which erupted exactly after 43 years of state's accession with the union of India. The armed struggle surfaced in the Kashmir valley in late 1989 with the demand to secede from the Union of India. Thereon, if a select lot of foreign media is constantly and continuously dubbing this particular region as a conflict zone in South-Asia, surely makes things look more worrisome, hence calls for the situation to be handled more diplomatically.

The supporters of secession movement in Kashmir valley have been constantly and continuously alleging of the non-existence of democracy in the state, human rights violation, deprivation of fundamental rights, religious atrocities, etc. and it was only in the year 1989-90 that some young minds from valley were enticed by some vested interests from both within and outside the country in the name of region, religion, community, freedom etc., resulting into their taking up to arms and joining the armed struggle to secede from the union of India.

The present study has been undertaken with the view to represent the pre and post 1989 sociopolitical scenario of the state, the secessionist struggle, which is around there for over a quarter of a century now, and to see, as how far the people of the state were actively involved in the democratic process of the country by participating in the electoral process of the country before 1989, during the active armed struggle, and now post active armed struggle period. Although, gun has gone silent in Kashmir valley, but surely resonate at times, only to make its presence felt, showcasing that the freedom struggle in Kashmir is still on.

\section{OBJECTIVES OF THE STUDY}

To examine whether the state of Jammu \& Kashmir is devoid of democracy or not and how far the state is a conflict zone in south Asia, as is propagated by a select lot of media.

To find out how far the secessionist movement is backed by the local populace and how far the populace of the state is denied of their fundamental or democratic rights by the union of India.

To determine the empirical facts about the public participation of Jammu \& Kashmir in general elections held in India during the period (1967-2014). The public participation of the state in these elections is a plebiscite or referendum of its own kind which is there since the merger of state in the union of India to which people voted time and again.

To draw a comparison of public participation in general elections of the Jammu \& Kashmir with the rest of India, along with the aspects like growth of elector in Jammu \& Kashmir during the subsequent general elections.

\section{DEMOGRAPHIC AND GEO-POLITICAL SCENARIO OF THE JAMMU \& KASHMIR STATE}

The state of Jammu \& Kashmir acceded to the Union of India immediately after attaining her independence. As is known, prior to her attaining independence on August 15, $1947^{[3]}$, India was divided into provinces and there were many princely states across the length and breadth of India and Jammu \& Kashmir state was one among these princely states. The Jammu \& Kashmir state like the rest of the states of the union of India acceded to union of India by signing a common accession document on October 26, 1947 and since then has become an integral part of the union of India.

As per 2011 population census of the country, the total population of the state is $1,25,48,926$ persons, having $68.70 \%$ literacy rate and is one of the least densely populated states of the county, 
having 124 persons per sq. $\mathrm{km}$ which at national level ranks $28^{\text {th }}$. The population density of the state has risen by 24 persons per sq $\mathrm{km}$ since the 2001 census, which the then was 100 persons per sq $\mathrm{km}$, spreads over an area of 2, 22,236 square kms. The Jammu \& Kashmir is in the extreme north of the Union of India, bordering with countries like, Pakistan, Afghanistan, China \& Tibet from three sides, while as Punjab and Himachal Pradesh are the only two states which are on the southern side of the state. These two states are the only corridor which connects the state with the southern plains of the rest of the country.

Topology of the Jammu \& Kashmir is entirely different from the rest of the states and union territories of the country. The state is naturally divided into three different geographical regions, each having diversity at almost every front, be it culturally, linguistically or even socioeconomically and nevertheless the temperate zones of each of these regions are totally different from each other.

Till March 30, 1965, the state of Jammu \& Kashmir used to have its own Prime Minister, as such, despite acceding to the union of India and being its federal constituent, people of Jammu \& Kashmir did not participate in the general elections of the India till 1967. This also reflects the fact that Jammu \& Kashmir was more an independent sovereign domain within the Indian domain with its own Prime Minister.

\section{REVIEW OF LITERATURE}

Political researchers all across the globe have undertaken a good number of studies pertaining to public participation in the democratic process of the countries through the electoral system. Researchers have been constantly arguing about the important aspects of the electoral system in reflecting the true democratic colour of the society, and to represent facts as they stand.

Tremblay (1996) in her study of the secessionist movement in Kashmir traces its roots with the nationalist movement of traditional Kashmir leadership against the Dogra rule of the 1940's which the then was working on the lines of goal of self determination and the secessionist movement of 1989 demands for autonomy, which ultimately transformed into freedom struggle and as such demand to secede from the union of India and declares the situation as overt political violence. Sikand (2002) while reviewing the socio-political scenario of Jammu \& Kashmir made observation about the rise and emergence of Jama'at-i-Islami in the state and its crucial role in the Kashmir polity since its inception, which dates back to 1940's but has gained silence during the course of armed struggle which is still on since 1989.

Widmalm (1997) deliberated on the rise and fall of democracy in Jammu \& Kashmir by finding it receding down since late 1970's and by the 1980's turned into a small civil war. The author has owed things to merging of incompatible identities by both India and Pakistan. The author describes that from Indian point Pakistan is the orchestrator of the insurgency in Kashmir while as Pakistan describes it as an outcome of the suppression of Kashmiries who want to join Pakistan and still more others see it as ethnic conflict prevalent at global level. The author further dubs the situation as a struggle between the state and central govt., elites. Kohili (1997) in his study, while deliberating about the rise of secessionist self-determination movements are more an outcome of demand for control and power by ethnic groups. The author identifies two dimensions relevant to the problems, one is the central authority which functions in that particular multicultural democracy, which should be well institutionalized, and thereon the willingness of ruling class to share some powers and resources with mobilized groups.

Desmod (1995) in his study talks about the killing of dozens of police men and officers by the JKLF guerrillas in the 1989, which left the middle class of Kashmir uncertain of the future. The author discusses of unleashing of chain of events following the kidnapping of Rubia Sayed, daughter of the then home minister of India, which ended with the release of five JKLF men. Gangly $(1996 ; 2006)$ discusses about the soared India and Pakistan relationship over Kashmir, since their gaining independence. The author talks about the constant and continuous rise of India as a global power, which is being least bothered by the Kashmir issue, but surely needs to be addressed diplomatically. The author has however shown concerns over the issues as India and Pakistan have 
already fought wars in 1947, 1965 and 1999 over Kashmir issue and related matters. The author talks about the presence of dozens of Islamic militant groups, their wrath resulted into fleeing of Kashmiri Pandits in 1989.

Pandita (2014) studied the presence of democracy in the state of Jammu \& Kashmir correlated the aspect with the public participation in the democratic process of the state, hence studied the assembly elections held in Jammu \& Kashmir during the period 1962-2008. The author observed that public participation of Jammu \& Kashmir in the assembly elections is very encouraging as average voter turnout during these assembly elections remained $59.48 \%$, which is almost equal to the average national voter turnout percentage and termed the armed struggle as undue and unjustified. The average voter turnout percentage in itself substantiates the existence of democracy in Jammu \& Kashmir, however the reasons for social un-rest can be different, but not that the state is devoid of democracy as is being dubbed by few.

Shastri (2014) corroborates the argument made by Kohli above that the rise of secessionist self-determination movements are more an outcome of demand for control and power by ethnic groups. The author deliberated that the anti-incumbency aspects come into play to show the public resentment through the electoral process. The author is of the view that the people may not look into the real issues, but may also some time vote in favour or against a particular political party when things otherwise may be other way round. The author undertook a study on the 2013 assembly elections held to the Karnataka state legislator and observed that the 2013 electoral mandate was more an unequivocal indictment against the existing government. The author is of the view that 2013 electoral verdict in Karnataka was not the pro-congress vote, but the anti incumbency factor and opines that individual perceptions of elector come into play while casting the vote. Kumar (2003) talked about the extreme fluidity of electoral permutations and combinations of Indian polity, both at the state and the central level.

It is not equally important that only the political war horses or their strong holds can always make merry of the electoral verdict. Haughton and Kar-Sovec (2013) studied the 2011 general elections in Slovenia and found that in the coalition era of politics smaller political parties prove as king makers. The authors also observed that there is growing conscience among electors where they don't hesitate in throwing out the corrupt and incompetent politicians and welcome the new political faces in their fold if they are ready to address their just and genuine demands. This is what we also saw in the recent Delhi assembly elections where Aam Aadmi Party (AAP) made a remarkable debut by fighting elections on genuine issues to which electorate of Delhi overwhelmingly responded to by bagging them 28 seats in 2013 and 67 out of 70 seats in 2014 assembly elections.

\section{SCOPE AND METHODOLOGY}

The study has been undertaken on the secondary data retrieved from the official website of the Election Commission of India on August 02, 2014, accessible at http://eci.gov.in. The data hosted on the website was more scattered and in semi-structured manner, as such structured to the suitability of the objectives defined.

The Scope of the present study is confined to the state of Jammu \& Kashmir. The study in general can be extended to other states of the country; however, there is every need to be careful with the generalization of the findings of this particular study.

\section{DATA ANALYSIS}

Brief explanations have been added against each table for better and clear grasping of the objectives of the present study. Mathematical and statistical tools have been applied to perform expressions like addition, subtraction, multiplication, division and the drawing percentage, etc. Percentage at most of the places has been drawn up to two decimal places, however, wherever warranted same has been expressed beyond. The data has not been rounded off at any place, as such may present a slight variation while computing data for $100 \%$ figure. 
Table-I Distribution \& Growth of Parties in State Elections

\begin{tabular}{|c|c|c|c|c|c|}
\hline Year & Seats & $\begin{array}{c}\text { National } \\
\text { Parties (\%) }\end{array}$ & $\begin{array}{c}\text { State Parties (Local) } \\
\text { +Independents (\%) }\end{array}$ & Total & Corresponding Growth (\%) \\
\hline $\mathbf{1 9 6 7}$ & 6 & NA & NA & NA & - \\
\hline $\mathbf{1 9 7 1}$ & 6 & 3 & 2 & 5 & - \\
\hline $\mathbf{1 9 7 7}$ & 6 & 2 & 2 & 4 & -20.00 \\
\hline $\mathbf{1 9 8 0}$ & 6 & 3 & 2 & 5 & 25.00 \\
\hline $\mathbf{1 9 8 4}$ & 6 & 3 & 3 & 6 & 20.00 \\
\hline $\mathbf{1 9 8 9}$ & 6 & 4 & 5 & 9 & 50.00 \\
\hline $\mathbf{1 9 9 6}$ & 6 & 4 & 3 & 7 & -28.57 \\
\hline $\mathbf{1 9 9 8}$ & 6 & 4 & 12 & 16 & 128.57 \\
\hline $\mathbf{1 9 9 9}$ & 6 & 6 & 16 & 22 & 37.50 \\
\hline $\mathbf{2 0 0 4}$ & 6 & 4 & 16 & 20 & -9.09 \\
\hline $\mathbf{2 0 0 9}$ & 6 & 7 & 18 & 25 & 25.00 \\
\hline $\mathbf{2 0 1 4}$ & 6 & 5 & 9 & 14 & -44.00 \\
\hline Avg & 6 & 4.09 & 8 & 12.09 & 16.76 \\
\hline
\end{tabular}

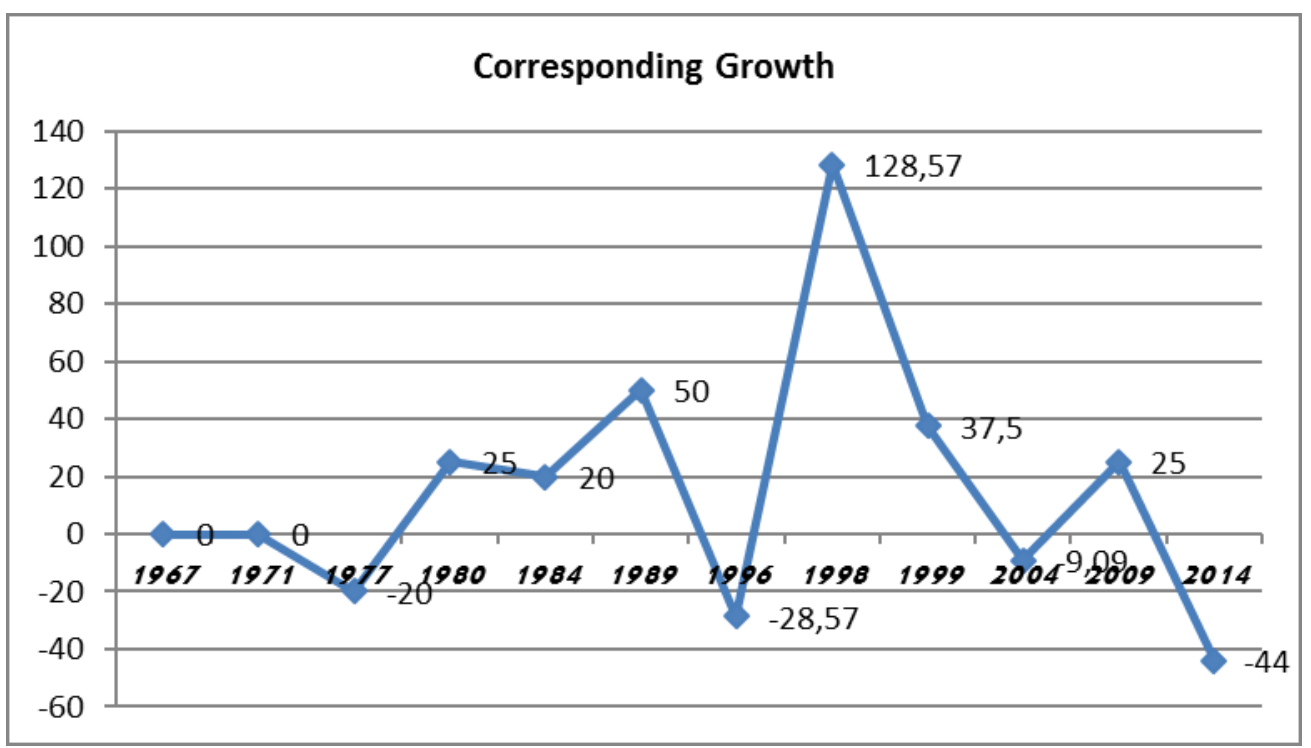

Figure 1 (Corresponding Growth Percentage of Political Parties)

Through there is a mixed trend in the corresponding growth of the contesting parties, but still the maximum 128.57\% corresponding growth in contesting parties was observed in the year 1998, which was one of most difficult phases of state politics, as social unrest in valley was high during those days. National parties grew from 2 to 7 in number and so grew local parties from 2 to 18 . On average 4 national parties and 8 local parties with an aggregate of average 12 political parties participated from Jammu \& Kashmir in each general election of the country, while as, on average, $16.76 \%$ corresponding growth was recorded in the increase in parties from each corresponding election, which is quite encouraging.

Table-IIDistribution of Candidates fielded by the parties and their success percentage

\begin{tabular}{|c|c|c|c|c|c|c|c|c|c|c|c|c|c|c|}
\hline & & & & & & & & \\
\hline Parties & Year $\rightarrow$ & 1967 & 1971 & 1977 & 1980 & 1984 & 1989 & 1996 & 1998 & 1999 & 2004 & 2009 & 2014 & Avg \\
\hline \multirow{4}{*}{$\begin{array}{c}\text { National } \\
\text { Parties }\end{array}$} & CF & 9 & 10 & 5 & 4 & 6 & 8 & 19 & 17 & 20 & 13 & 13 & 18 & 11.83 \\
\hline & $\mathrm{CE}$ & 5 & 5 & 3 & 2 & 3 & 2 & 6 & 3 & 2 & 2 & 2 & 3 & 3.16 \\
\hline & SU\% & 55.55 & 50.00 & 60.00 & 50.00 & 50.00 & 25.00 & 31.57 & 17.64 & 10.00 & 15.38 & 15.35 & 16.66 & 26.71 \\
\hline & SH\% & 83.33 & 83.33 & 50.00 & 33.33 & 50.00 & 33.33 & 100 & 50.00 & 33.33 & 33.33 & 33.33 & 50.00 & 52.66 \\
\hline \multirow{4}{*}{$\begin{array}{l}\text { State Parties } \\
\text { (Local- } \\
\text { nonlocal) }\end{array}$} & CF & 5 & 2 & 3 & 5 & 7 & 6 & 7 & 24 & 35 & 33 & 40 & 26 & 16.03 \\
\hline & $\mathbf{C E}$ & 1 & 0 & 2 & 3 & 3 & 4 & 0 & 3 & 4 & 3 & 3 & 3 & 2.41 \\
\hline & SU\% & 20.00 & 0 & 66.66 & 60.00 & 42.85 & 66.66 & 0 & 12.50 & 11.42 & 9.09 & 7.50 & 11.53 & 15.03 \\
\hline & SH\% & 16.66 & 0 & 33.33 & 50.00 & 50.00 & 66.66 & 0 & 50.00 & 66.66 & 50.00 & 50.00 & 50.00 & 40.16 \\
\hline \multirow{4}{*}{ Independents } & CF & 1 & 20 & 21 & 20 & 35 & 49 & 84 & 45 & 28 & 37 & 28 & 33 & 33.41 \\
\hline & $\mathbf{C E}$ & 0 & 1 & 1 & 1 & 0 & 1 & 0 & 0 & 0 & 1 & 1 & 0 & 0.50 \\
\hline & SU\% & 0 & 5.00 & 4.76 & 5.00 & 0 & 2.04 & 0 & 0 & 0 & 2.70 & 3.57 & 0 & 1.49 \\
\hline & SH\% & 0 & 16.66 & 16.66 & 16.66 & 0 & 16.66 & 0 & 0 & 0 & 16.66 & 16.66 & 0 & 24.83 \\
\hline \multirow{2}{*}{ Total } & $\mathbf{C F}$ & 15 & 32 & 29 & 29 & 48 & 63 & 110 & 86 & 83 & 83 & 81 & 77 & 61.33 \\
\hline & $\mathbf{C E}$ & 6 & 6 & 6 & 6 & 6 & 6 & 6 & 6 & 6 & 6 & 6 & 6 & 6 \\
\hline
\end{tabular}

CF-Candidates Fielded, CE-Candidates Elected, SU\%-Success Percentage, SH\%-Share Percentage 


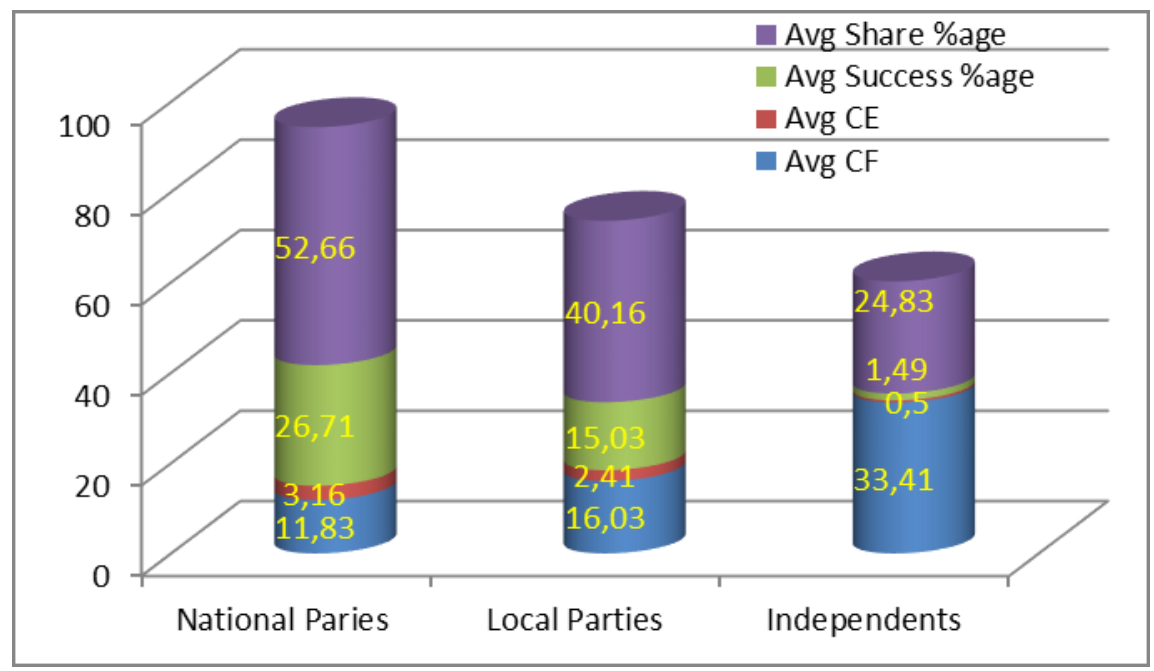

Figure 2 (Average Distribution Representation of Candidates Fielded, Candidates, Elected, Success Percentage and Share Percentage of candidates from National and Local parties along with Independents)

On average $52.66 \%$ seats were won by national level political parties, $40.16 \%$ by state level political parties and $24.83 \%$ by independents with an average success percentage of $26.71 \%$, $15.03 \%$ and $1.49 \%$ respectively. The better success percentage of candidates fielded by national level political parties is an indicative of the fact that people of the state are not biased on the basis of candidate's affiliation with the type and kind of political party and as such show full faith in the democratic values of the country and somewhere have more preference towards electing those candidates, who are actively engaged with national polity having the patronage of central leadership.

Table-III Candidates per Constituency

\begin{tabular}{|c|c|c|c|c|c|}
\hline \multirow{2}{*}{ Year } & \multirow{2}{*}{$\begin{array}{l}\text { Total } \\
\text { Seats }\end{array}$} & \multicolumn{4}{|c|}{ Candidate Fielded } \\
\cline { 3 - 6 } & & Min & Max & Avg & Total \\
\hline 1967 & 6 & 1 & 4 & 3 & 15 \\
\hline 1971 & 6 & 2 & 9 & 5 & 32 \\
\hline 1977 & 6 & 2 & 9 & 5 & 29 \\
\hline 1980 & 6 & 1 & 9 & 5 & 29 \\
\hline 1984 & 6 & 3 & 16 & 8 & 48 \\
\hline 1989 & 6 & 1 & 24 & 11 & 63 \\
\hline 1996 & 6 & 3 & 40 & 18 & 110 \\
\hline 1998 & 6 & 4 & 29 & 14 & 86 \\
\hline 1999 & 6 & 7 & 22 & 14 & 83 \\
\hline 2004 & 6 & 4 & 26 & 14 & 83 \\
\hline 2009 & 6 & 5 & 21 & 13 & 81 \\
\hline 2014 & 6 & 4 & 19 & 13 & 77 \\
\hline Avg & 6 & 3.08 & 19 & 10.25 & 61.33 \\
\hline
\end{tabular}

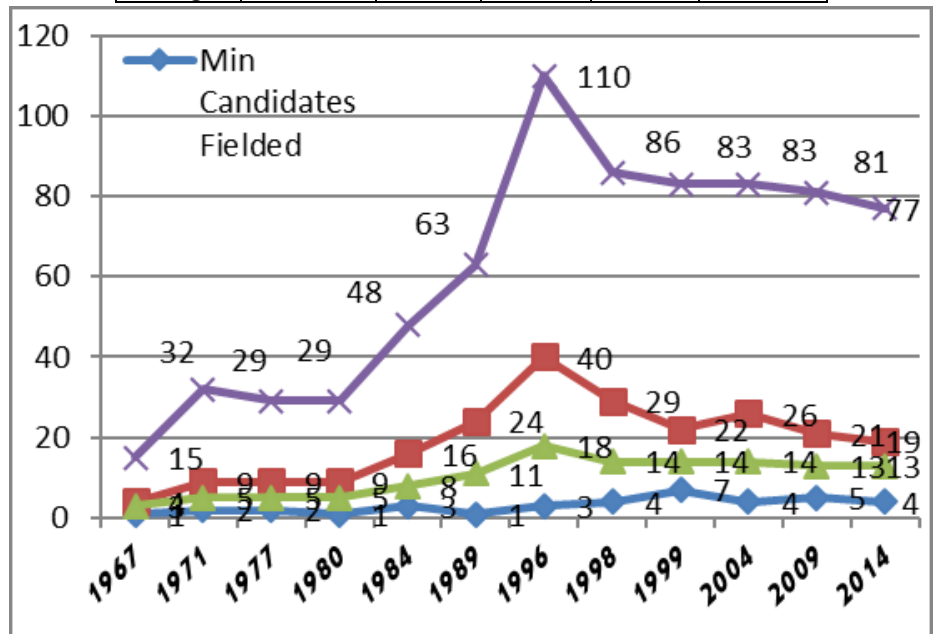

Figure 3 (Frequency curve of total, maximum, minimum and average contestants) 
The state of Jammu \& Kashmir has a total of 6 Lok Sabha (Parliamentary) seats. During all these elections, a minimum of 1 candidate was fielded in the year 1967, 1980 \& 1989 for a single seat each, while as a maximum of 40 candidates contested on a single seat in the year 1996. The period 1993 to 1998 witnessed the highest social unrest in Kashmir valley, but people (bereaving) defying all terrorist threats not just participated in these general elections, but also recorded the maximum 110 candidates who tried their luck in the 1996 elections. On average, a minimum of 3 candidates fought elections on each seat with a maximum of 19 candidates, which on average made 10 candidates for each seat each year, with an average of 61 candidates participated each year the general elections of India.

Table-IV Distribution of Candidates fielded

\begin{tabular}{|c|c|c|c|c|c|c|c|c|c|}
\hline \multirow{2}{*}{ Year } & \multirow{2}{*}{$\begin{array}{l}\text { Total } \\
\text { Seats }\end{array}$} & \multicolumn{3}{|c|}{$\begin{array}{c}\text { Candidate Fielded \& Share } \\
\text { Percentage }\end{array}$} & \multicolumn{2}{c|}{$\begin{array}{c}\text { Candidates Elected \& } \\
\text { Share Percentage }\end{array}$} & \multicolumn{2}{c|}{ Success \%age } & \multirow{2}{*}{ Total } \\
\cline { 3 - 10 } & & Male (SH \%) & $\begin{array}{c}\text { Female (SH } \\
\text { \%) }\end{array}$ & Total & Male (SH \%) & $\begin{array}{c}\text { Female (SH } \\
\text { \%) }\end{array}$ & Male & Female & \\
\hline 1967 & 6 & $15(100)$ & $0(0)$ & 15 & $6(100)$ & $0(0)$ & 40.00 & 0 & 6 \\
\hline 1971 & 6 & $32(100)$ & $0(0)$ & 32 & $6(100)$ & $0(0)$ & 18.75 & 0 & 6 \\
\hline 1977 & 6 & $27(93.10)$ & $2(6.90)$ & 29 & $4(66.66)$ & $2(33.34)$ & 14.81 & 100.00 & 6 \\
\hline 1980 & 6 & $29(100)$ & $0(0)$ & 29 & $6(100)$ & $0(0)$ & 20.68 & 0 & 6 \\
\hline 1984 & 6 & $47(97.80)$ & $1(2.08)$ & 48 & $5(83.33)$ & $1(16.67)$ & 10.63 & 100.00 & 6 \\
\hline 1989 & 6 & $62(98.42)$ & $1(1.58)$ & 63 & $6(100)$ & $0(0)$ & 9.67 & 0 & 6 \\
\hline 1996 & 6 & $102(92.72)$ & $8(7.28)$ & 110 & $6(100)$ & $0(0)$ & 5.88 & 0 & 6 \\
\hline 1998 & 6 & $84(97.67)$ & $2(2.33)$ & 86 & $6(100)$ & $0(0)$ & 7.14 & 0 & 6 \\
\hline 1999 & 6 & $77(92.77)$ & $6(7.23)$ & 83 & $6(100)$ & $0(0)$ & 7.79 & 0 & 6 \\
\hline 2004 & 6 & $79(92.77)$ & $4(4.82)$ & 83 & $5(83.33)$ & $1(16.67)$ & 6.32 & 25.00 & 6 \\
\hline 2009 & 6 & $75(92.59)$ & $6(7.41)$ & 81 & $6(100)$ & $0(0)$ & 8.00 & 0 & 6 \\
\hline 2014 & 6 & $74(96.10)$ & $3(3.90)$ & 77 & $5(83.33)$ & $1(16.67)$ & 6.75 & 33.33 & 6 \\
\hline Avg & 6 & $58.58(95.51)$ & $2.75(4.48)$ & 61.33 & $5.58(93.00)$ & $0.42(7.00)$ & 9.52 & 15.27 & 6 \\
\hline
\end{tabular}

Participation of women candidates in the general elections from the state of Jammu \& Kashmir is not that encouraging. During the year 1967, 1971 \& 1980 not even a single woman candidate contested the general elections and those who contested in the remaining general elections held in the state success was witnessed only in the year 1977, 1984, $2004 \& 2014$. During the entire history of general elections held in the state of Jammu \& Kashmir, so far only 5 female candidates have been elected to the parliament with an average success of $7 \%$. This also means that $93 \%$ candidates who represented the people of Jammu \& Kashmir in the parliament in its entire history were males. Even the ratio of male female contestants is equally disturbing, as against $95.51 \%$ males only $4.48 \%$ females have contested the general election in the entire history of Jammu \& Kashmir.

Table-V Number and Type of Constituencies

\begin{tabular}{|c|c|c|c|c|c|c|c|}
\hline \multirow{2}{*}{ Year } & \multicolumn{4}{|c|}{ Seat Distribution } & \multicolumn{3}{|c|}{ Percentage Share } \\
\cline { 2 - 8 } & Gen & SC & ST & Total & Gen & SC & ST \\
\hline 1967 & 6 & 0 & 0 & 6 & 100 & 0 & 0 \\
\hline 1971 & 6 & 0 & 0 & 6 & 100 & 0 & 0 \\
\hline 1977 & 6 & 0 & 0 & 6 & 100 & 0 & 0 \\
\hline 1980 & 6 & 0 & 0 & 6 & 100 & 0 & 0 \\
\hline 1984 & 6 & 0 & 0 & 6 & 100 & 0 & 0 \\
\hline 1989 & 6 & 0 & 0 & 6 & 100 & 0 & 0 \\
\hline 1996 & 6 & 0 & 0 & 6 & 100 & 0 & 0 \\
\hline 1998 & 6 & 0 & 0 & 6 & 100 & 0 & 0 \\
\hline 1999 & 6 & 0 & 0 & 6 & 100 & 0 & 0 \\
\hline 2004 & 6 & 0 & 0 & 6 & 100 & 0 & 0 \\
\hline 2009 & 6 & 0 & 0 & 6 & 100 & 0 & 0 \\
\hline 2014 & 6 & 0 & 0 & 6 & 100 & 0 & 0 \\
\hline
\end{tabular}


With the view to uplift the deprived and backward sections of society in India, Govt. of India has made constitutional provisions, whereby Lok Sabha seats have been reserved all over county for these sections of society mostly comprising of Scheduled Casts (SC) and Scheduled Tribes (ST). This provision stands equally extended to the state of Jammu \& Kashmir, but till date, no such reservation has been extended to these sections of society in the state of Jammu \& Kashmir, despite having large SC \& ST population, but given their scattered settlements reserving a seat for such section is practically difficult.

Table-VI Election wise status of electors in Jammu \& Kashmir

\begin{tabular}{|c|c|c|c|c|c|c|c|c|c|c|}
\hline \multirow{2}{*}{ Year } & \multirow{2}{*}{$\begin{array}{l}\text { No of } \\
\text { Seats }\end{array}$} & \multicolumn{3}{|c|}{$\begin{array}{c}\text { Total } \\
\text { Electors }\end{array}$} & \multicolumn{3}{|c|}{ Turnout } & \multicolumn{2}{|c|}{$\begin{array}{l}\text { Voter Turnout } \\
\text { (Share \%age) }\end{array}$} & \multirow{2}{*}{$\begin{array}{c}\text { \%age } \\
\text { Voter } \\
\text { Turnou }\end{array}$} \\
\hline & & Male & Female & Total & Male & Female & Total & Male & Female & \\
\hline 1967 & 6 & 940847 & 640293 & 1581140 & 538608 & 333496 & 872104 & 61.75 & 38.25 & 55.16 \\
\hline 1971 & 6 & 1150452 & 947171 & 2097623 & 777830 & 441255 & 1219085 & 63.80 & 36.20 & 58.12 \\
\hline 1977 & 6 & 1341600 & 1215822 & 2557422 & 899679 & 579835 & 1479514 & 60.80 & 39.20 & 57.85 \\
\hline 1980 & 6 & 1557582 & 1310055 & 2867637 & 844012 & 533976 & 1377988 & 61.24 & 38.76 & 48.05 \\
\hline 1984 & 6 & 1824779 & 1575231 & 3400010 & 1291779 & 966334 & 2258113 & 57.20 & 42.80 & 66.41 \\
\hline 1989 & 6 & 2231312 & 1923985 & 4155297 & 659387 & 407492 & 1066879 & 61.80 & 38.20 & 25.68 \\
\hline 1996 & 6 & 2378717 & 2076992 & 4455709 & 1369602 & 811992 & 2181594 & 62.77 & 37.23 & 48.96 \\
\hline 1998 & 6 & 2723014 & 2299768 & 5022782 & 1318244 & 902127 & 2220371 & 59.37 & 40.63 & 44.21 \\
\hline 1999 & 6 & 2725461 & 2304633 & 5030094 & 968904 & 658041 & 1626945 & 59.55 & 40.45 & 32.34 \\
\hline 2004 & 6 & 3468235 & 2899880 & 6368115 & 1391263 & 841489 & 2241729 & 62.06 & 37.94 & 35.20 \\
\hline 2009 & 6 & 3421708 & 3151188 & 6572896 & 1539539 & 1065887 & 2607335 & 59.04 & 40.96 & 39.64 \\
\hline 2014 & 6 & 3802021 & 3400142 & 7202163 & 1927584 & 1639289 & 3547806 & 50.70 & 48.21 & 49.52 \\
\hline Avg & 6 & 2297144 & 1978763 & 4275907 & 1127202 & 765101 & 1891621 & 60.00 & 39.90 & 46.76 \\
\hline
\end{tabular}

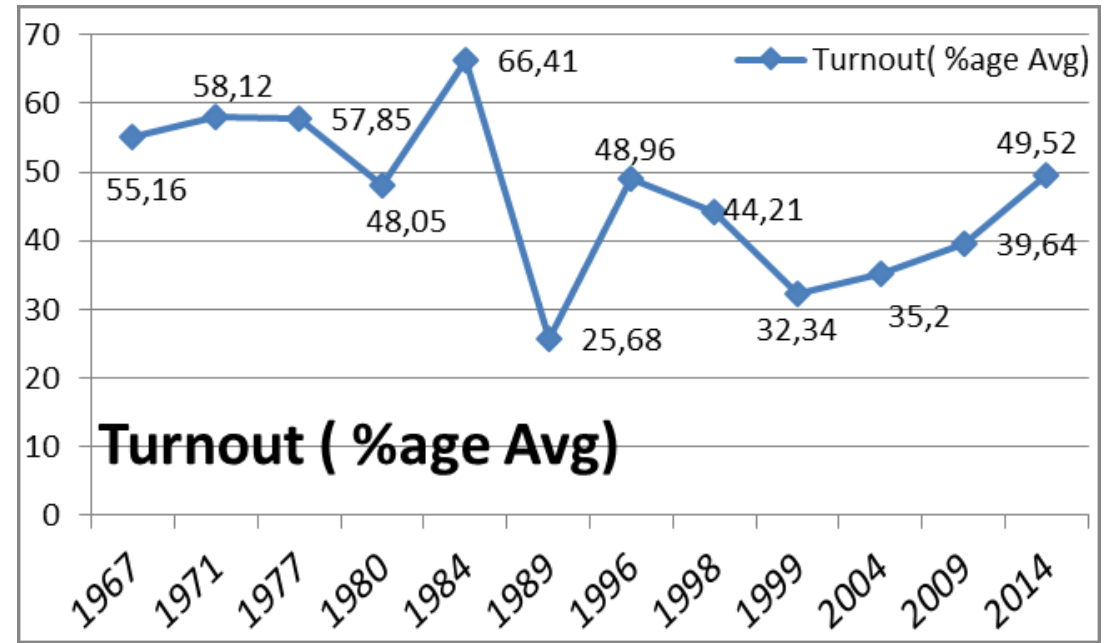

Figure 4 (Voter turnout percentage curve of state electors during each general election)

It's a proven fact in the Indian social setup, compared to females, males have been very much active in their participation in the general elections and so holds true of Jammu \& Kashmir. On average, compared to $39.90 \%$ female electors, $60 \%$ male electors participated actively in all the general elections held in the state during the period of study. On average, $46.76 \%$ electors of Jammu \& Kashmir exercised their democratic franchise in each general election. A maximum of $66.41 \%$ voter turnout was recorded in the year 1984, mostly owed to the death of the then Prime Minister of India, Smt. Indira Gandhi, which took the whole country into its savvy, as $63.56 \%$ voter turnout was recorded in the whole of India during the 1984 elections the highest in the history of India. While as, the lowest voter turnout $25.68 \%$ was recorded in the state during the 1989 general elections, the year which witnessed the surfacing of the armed secessionist movement in Kashmir valley. 
Table-VII Candidates Forfeited Deposits

\begin{tabular}{|c|c|c|c|c|c|c|c|c|c|}
\hline \multirow{2}{*}{ Year } & \multicolumn{3}{|c|}{ Contestants } & \multicolumn{3}{c|}{ Elected } & \multicolumn{3}{c|}{ Forfeited Deposits } \\
\cline { 2 - 11 } & Male & Female & Total & Male & Female & Total & Male & Female & Total \\
\hline 1967 & 15 & 0 & 15 & 6 & 0 & 6 & 5 & 0 & 5 \\
\hline 1971 & 32 & 0 & 32 & 6 & 0 & 6 & 20 & 0 & 20 \\
\hline 1977 & 27 & 2 & 29 & 4 & 2 & 6 & 17 & 0 & 17 \\
\hline 1980 & 29 & 0 & 29 & 6 & 0 & 6 & 17 & 0 & 17 \\
\hline 1984 & 47 & 1 & 48 & 5 & 1 & 6 & 35 & 0 & 35 \\
\hline 1989 & 62 & 1 & 63 & 6 & 0 & 6 & 53 & 1 & 54 \\
\hline 1996 & 102 & 8 & 110 & 6 & 0 & 6 & 91 & 8 & 99 \\
\hline 1998 & 84 & 2 & 86 & 6 & 0 & 6 & 71 & 2 & 73 \\
\hline 1999 & 77 & 6 & 83 & 6 & 0 & 6 & 63 & 5 & 68 \\
\hline 2004 & 79 & 4 & 83 & 5 & 1 & 6 & 67 & 3 & 70 \\
\hline 2009 & 75 & 6 & 81 & 6 & 0 & 6 & 62 & 5 & 67 \\
\hline 2014 & 74 & 3 & 77 & 5 & 1 & 6 & 62 & 2 & 64 \\
\hline Avg. & 58.58 & 2.75 & 61.33 & 5.58 & 0.42 & 6 & 46.91 & 2.16 & 49.03 \\
$(\%)$ & $(95.51)$ & $(4.48)$ & & $(93.00)$ & $(7.00)$ & & $(95.67)$ & $(4.40)$ & $(79.94)$ \\
\hline
\end{tabular}

The above table may not hold that relevance to the present study, but it is equally important to note that on average nearly $80 \%$ contestants of the state forfeited their deposits during general elections, while as the forfeiture percentage at national level stands $66.95 \%$, nearly $13 \%$ more than the national average. So one can make a clear reading of the these facts that people of Jammu \& Kashmir show more enthusiasm and participation in the democratic exercise of the country, a nice negation that the state is devoid of democracy.

Table-VIII Distribution of Polling Station with Average Electors

\begin{tabular}{|c|c|c|c|c|c|}
\hline Year & $\begin{array}{c}\text { No of } \\
\text { Constituencies }\end{array}$ & $\begin{array}{c}\text { No of } \\
\text { polling } \\
\text { Stations }\end{array}$ & $\begin{array}{c}\text { Corresponding } \\
\text { Growth (\%) }\end{array}$ & $\begin{array}{c}\text { Average } \\
\text { Polling } \\
\text { Stations }\end{array}$ & $\begin{array}{c}\text { Average } \\
\text { Electors per } \\
\text { Polling Station }\end{array}$ \\
\hline 1967 & 6 & 2525 & - & 421 & 626 \\
\hline 1971 & 6 & 3094 & $569(22.53)$ & 516 & 678 \\
\hline 1972 & 6 & 3604 & $510(16.48)$ & 601 & 710 \\
\hline 1980 & 6 & 4364 & $760(21.08)$ & 727 & 657 \\
\hline 1984 & 6 & 5349 & $985(22.57)$ & 891 & 636 \\
\hline 1989 & 6 & 6002 & $653(12.20)$ & 1000 & 692 \\
\hline 1996 & 6 & 6158 & $156(2.59)$ & 1026 & 724 \\
\hline 1998 & 6 & 6512 & $354(5.74)$ & 1085 & 771 \\
\hline 1999 & 6 & 6513 & $1(0.01)$ & 1085 & 772 \\
\hline 2004 & 6 & 7215 & $702(10.77)$ & 1202 & 827 \\
\hline 2009 & 6 & 9129 & $1914(26.52)$ & 1521 & 720 \\
\hline 2014 & 6 & 9633 & $504(5.52)$ & 1605 & 747 \\
\hline Avg. & 6 & 5841.50 & $(12.16)$ & 973 & 713 \\
\hline
\end{tabular}

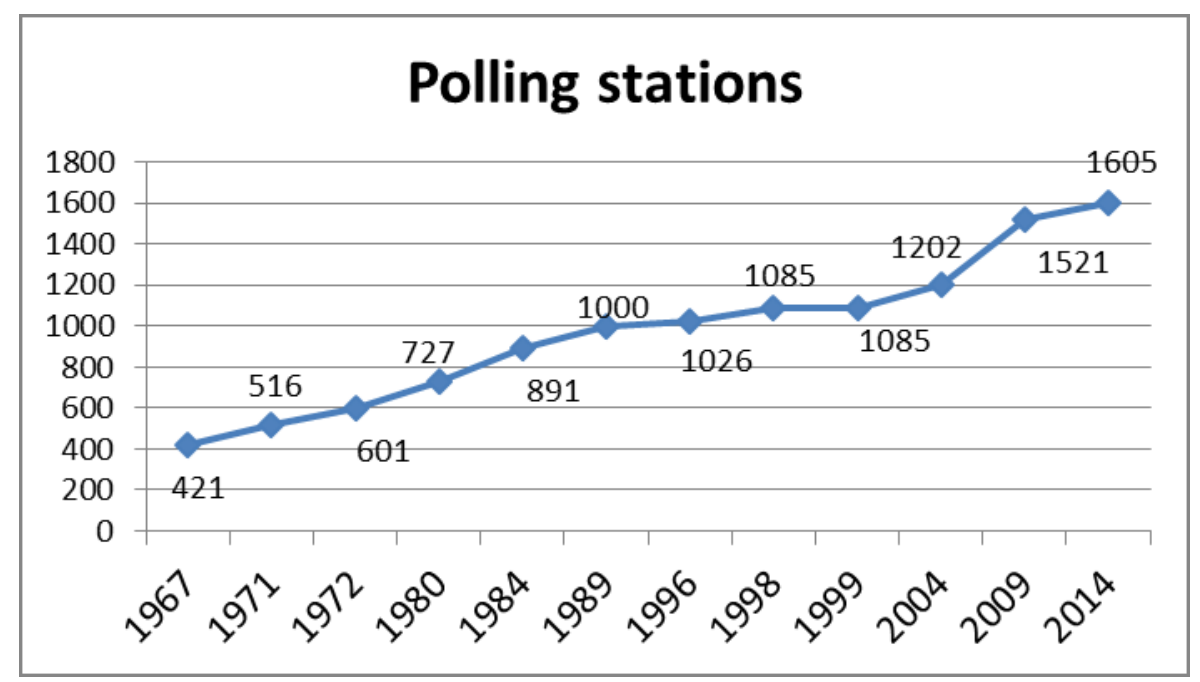

Figure 5 (Growth distribution curve of increase in polling stations during each election held in the state) 
To facilitate and to enhance the public participation in the democratic process of the country, on average, during each general election the polling stations in the state of Jammu \& Kashmir have increased by $12.16 \%$ from each corresponding election. On average 5841 polling stations have covered each general election in the state with an average 973 polling stations per constituency with as many as 713 electors registered with each polling station.

Table-IX Party Wise Performance Distribution of candidates fielded and Elected

\begin{tabular}{|c|c|c|c|c|c|c|c|c|c|c|c|c|c|c|c|}
\hline \multicolumn{3}{|c|}{ Party Name } & 1967 & 1971 & 1977 & 1980 & 1984 & 1989 & 1996 & 1998 & 1999 & 2004 & 2009 & 2014 & Avg \\
\hline \multirow{2}{*}{$\begin{array}{c}\text { National } \\
\text { conference }\end{array}$} & \multirow{2}{*}{ JKN } & $\mathbf{C F}$ & 4 & & 3 & 5 & 5 & 3 & & 6 & 6 & 6 & 3 & 3 & 4.40 \\
\hline & & $\mathbf{C E}$ & 1 & & 2 & 3 & 3 & 3 & & 3 & 4 & 2 & 3 & 0 & 2.40 \\
\hline \multirow{2}{*}{$\begin{array}{c}\text { Indian } \\
\text { National } \\
\text { Congress }\end{array}$} & \multirow{2}{*}{ INC } & $\mathbf{C F}$ & 6 & 6 & 3 & 2 & 4 & 3 & 6 & 6 & 5 & 6 & 6 & 3 & 4.66 \\
\hline & & $\mathbf{C E}$ & 5 & 5 & 3 & 1 & 3 & 2 & 4 & 1 & 0 & 2 & 2 & 0 & 2.33 \\
\hline \multirow{2}{*}{$\begin{array}{c}\text { Bhartiya Janta } \\
\text { Party }\end{array}$} & \multirow{2}{*}{ BJP } & $\mathbf{C F}$ & & & & & 1 & 2 & 5 & 6 & 6 & 6 & 6 & 6 & 4.75 \\
\hline & & $\mathbf{C E}$ & & & & & 0 & 0 & 1 & 2 & 2 & 0 & 0 & 3 & 1.00 \\
\hline \multirow{2}{*}{$\begin{array}{c}\text { JKN Panthers } \\
\text { Party }\end{array}$} & \multirow{2}{*}{ JPP } & $\mathbf{C F}$ & & & & & 1 & 1 & 5 & & 3 & 4 & 2 & 5 & 3.00 \\
\hline & & $\mathbf{C E}$ & & & & & 0 & 0 & 0 & & 0 & 0 & 0 & 0 & 0 \\
\hline \multirow{2}{*}{$\begin{array}{c}\text { Bhujan Samaj } \\
\text { Party }\end{array}$} & \multirow{2}{*}{ BSP } & $\mathbf{C F}$ & & & & & & 1 & 2 & 4 & & 3 & & 5 & 3.00 \\
\hline & & $\mathbf{C E}$ & & & & & & 0 & 0 & 0 & & 0 & & 0 & 0 \\
\hline \multirow{2}{*}{$\begin{array}{c}\text { Peoples Dem } \\
\text { Party }\end{array}$} & \multirow{2}{*}{ PDP } & $\mathbf{C F}$ & & & & & & & & & & 3 & 6 & 5 & 4.66 \\
\hline & & $\mathbf{C E}$ & & & & & & & & & & 1 & 0 & 3 & 1.33 \\
\hline \multirow{2}{*}{ Independents } & \multirow{2}{*}{ IND } & $\mathbf{C F}$ & 1 & 20 & 21 & 20 & 35 & 49 & 84 & 45 & 28 & 37 & 28 & 32 & 33.33 \\
\hline & & $\mathbf{C E}$ & 0 & 1 & 1 & 1 & 0 & 1 & 0 & 0 & 0 & 1 & 1 & 0 & 0.50 \\
\hline \multirow{2}{*}{ Others } & \multirow{2}{*}{ OTH } & $\mathbf{C F}$ & 4 & 6 & 2 & 2 & 2 & 4 & 8 & 19 & 35 & 21 & 36 & 18 & 27.50 \\
\hline & & $\mathbf{C E}$ & 0 & 0 & 0 & 1 & 0 & 0 & 1 & 0 & 0 & 0 & 0 & 0 & 0 \\
\hline \multirow{2}{*}{ Total } & \multirow{2}{*}{ TOT } & CF & 15 & 32 & 29 & 29 & 48 & 63 & 110 & 86 & 83 & 83 & 81 & 77 & 61.33 \\
\hline & & $\mathrm{CE}$ & 6 & 6 & 6 & 6 & 6 & 6 & 6 & 6 & 6 & 6 & 6 & 6 & 6 \\
\hline
\end{tabular}

CF-Candidates Fielded, CE-Candidates Elected

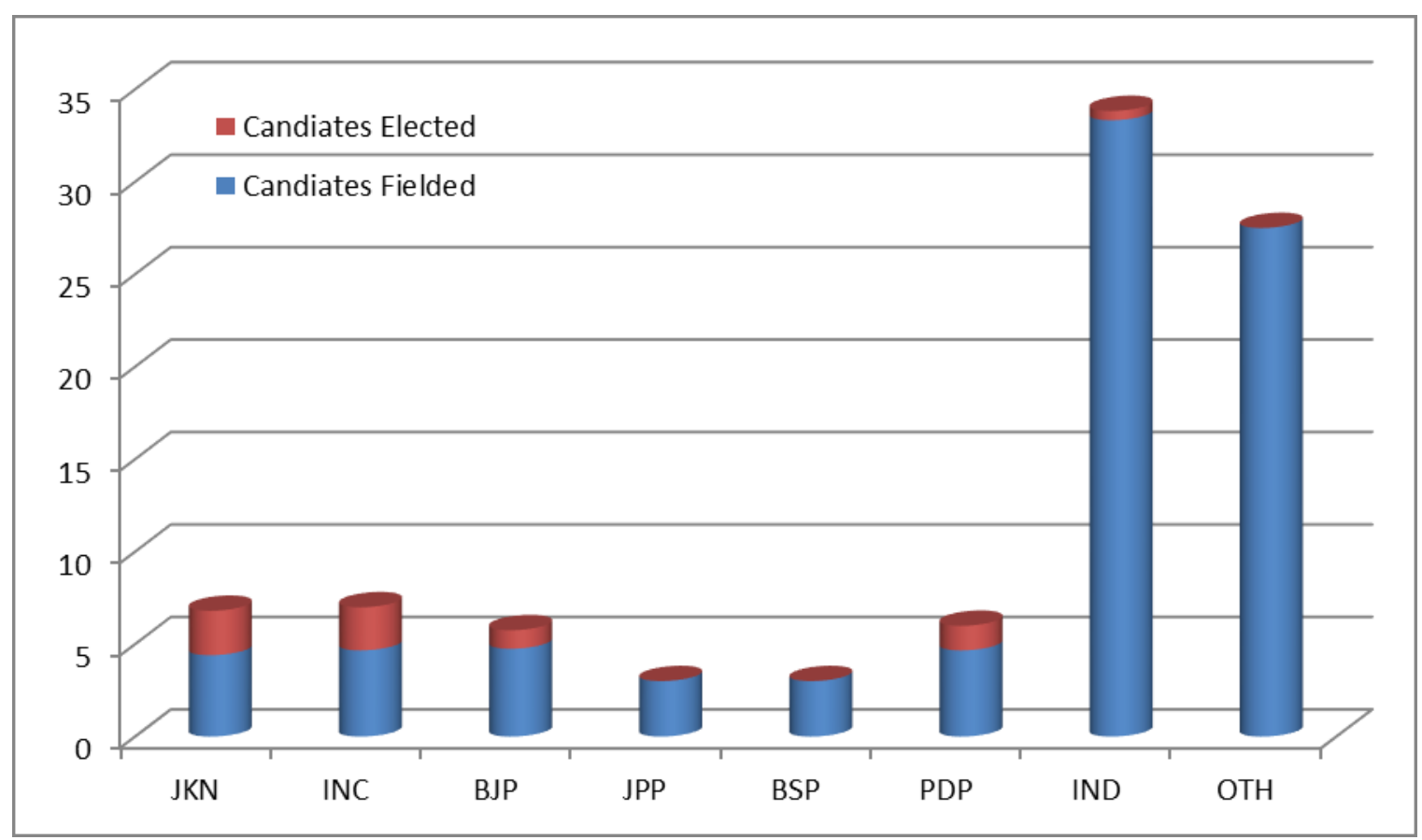

Figure 6 (Party wise bar distribution of candidates filed and the candidate elected during all the elections held in the state)

The Indian National Congress on average fielded 4.66 candidates in each general election with an average success of 2.33 candidates. Accordingly BJP on average fielded 4.75 candidates with an average success of 1 candidate, while as BSP on average fielded 3 candidates during each general election with no success till date. On the other hand among state level political parties, NC on average fielded 4.40 candidates in each general election with an average success of 2.40 candidates. Jammu \& Kashmir National Panthers Party (JKNPP) made its debut during the 1984 general 
elections and on average fielded 3 candidates during each general election, with no success till date. The Peoples Democratic Party (PDP) came to the national scene by contesting 2004 general elections. The party so far contested in only three general elections by fielding on average 4.66 candidates in each election with an average success of 1.33 candidates.

Table-X Party Wise valid votes Obtained

\begin{tabular}{|c|c|c|c|c|c|c|c|c|c|c|c|}
\hline Year & & JKN & INC & BJP & JPP & BSP & JD & PDP & IND & OTH & VV \\
\hline \multirow{2}{*}{1967} & VO & 210020 & 425668 & & & & & & 4781 & 202155 & \multirow{2}{*}{842624} \\
\hline & $\% \mathrm{~S}$ & 24.92 & 50.51 & & & & & & 0.56 & 23.99 & \\
\hline \multirow{2}{*}{1971} & VO & & 630690 & & & & & & 375316 & 160740 & \multirow{2}{*}{1166746} \\
\hline & $\% \mathrm{~S}$ & & 54.05 & & & & & & 32.16 & 13.77 & \\
\hline \multirow{2}{*}{1977} & VO & 483192 & 233144 & & & & & & 590790 & 117198 & \multirow{2}{*}{1424324} \\
\hline & $\% \mathrm{~S}$ & 33.92 & 16.36 & & & & & & 41.47 & 8.22 & \\
\hline \multirow[b]{2}{*}{1980} & VO & 493143 & 194138 & & & & & & 284459 & 365263 & \multirow{2}{*}{1337003} \\
\hline & $\% \mathrm{~S}$ & 36.88 & 14.52 & & & & & & 21.27 & 27.31 & \\
\hline \multirow{2}{*}{1984} & VO & 1010243 & 661435 & 37309 & 95149 & & & & 380951 & 3069 & \multirow{2}{*}{2188156} \\
\hline & $\% \mathrm{~S}$ & 46.16 & 30.22 & 1.70 & 4.34 & & & & 17.40 & 0.14 & \\
\hline \multirow{2}{*}{1989} & VO & 71194 & 407474 & 74832 & 22625 & 42453 & 314357 & & 100419 & 12767 & \multirow{2}{*}{1046121} \\
\hline & $\% \mathrm{~S}$ & 6.80 & 38.95 & 7.15 & 2.16 & 4.05 & 30.04 & & 9.59 & 1.22 & \\
\hline \multirow{2}{*}{1996} & VO & & 569942 & 395300 & 99599 & 123591 & 366074 & & 504098 & 17276 & \multirow{2}{*}{2075880} \\
\hline & $\% \mathrm{~S}$ & & 27.45 & 19.04 & 4.79 & 5.95 & 17.63 & & 24.28 & 0.83 & \\
\hline \multirow{2}{*}{1998} & VO & & & 618155 & & & & & & 1540442 & \multirow{2}{*}{2158597} \\
\hline & $\% \mathrm{~S}$ & & & 28.63 & & & & & & 71.36 & \\
\hline \multirow{2}{*}{1999} & VO & 454481 & 280065 & 495715 & 13890 & 75943 & & & 151229 & 99241 & \multirow{2}{*}{1570564} \\
\hline & $\% \mathrm{~S}$ & 28.93 & 17.83 & 31.56 & 0.88 & 4.83 & & & 9.62 & 6.31 & \\
\hline \multirow{2}{*}{2004} & VO & 493067 & 623182 & 515965 & 67619 & 49754 & & 267457 & 165352 & 56928 & \multirow{2}{*}{2239342} \\
\hline & $\% \mathrm{~S}$ & 22.01 & 27.82 & 23.04 & 3.01 & 2.22 & & 11.94 & 7.38 & 2.54 & \\
\hline \multirow{2}{*}{2009} & VO & 498374 & & & 73293 & & & 522760 & & 1511539 & \multirow{2}{*}{2605966} \\
\hline & $\% \mathrm{~S}$ & 19.12 & & & 2.81 & & & 20.06 & & 58.00 & \\
\hline \multirow[b]{2}{*}{2014} & VO & 396713 & 845510 & 1154220 & 43452 & 54091 & & 732644 & 223498 & 116735 & \multirow{2}{*}{3566863} \\
\hline & $\% \mathrm{~S}$ & 11.12 & 23.70 & 32.35 & 1.21 & 1.51 & & 20.54 & 6.26 & 3.27 & \\
\hline \multirow{2}{*}{ Total } & VO & 4110427 & 4871248 & 3291496 & 415627 & 345832 & 680431 & 1522861 & 2780893 & 4203353 & \multirow{2}{*}{22222186} \\
\hline & $\% \mathrm{~S}$ & 18.49 & 21.92 & 14.81 & 1.87 & 1.55 & 3.06 & 6.85 & 12.51 & 18.91 & \\
\hline
\end{tabular}

VV-Valid Votes, VO-Votes Obtained, \%S-Percentage Share

JKN-Jammu \& Kashmir National Conference, INC - Indian National Congress, BJP-Bhartiya Janta Party, JKNPP-Jammu \& Kashmir National Panthers Party, BSP-Bhujan Samaj Party, JD- Janta Dal, PDP- Peoples Democratic party, IND-Independents, OTH-Others

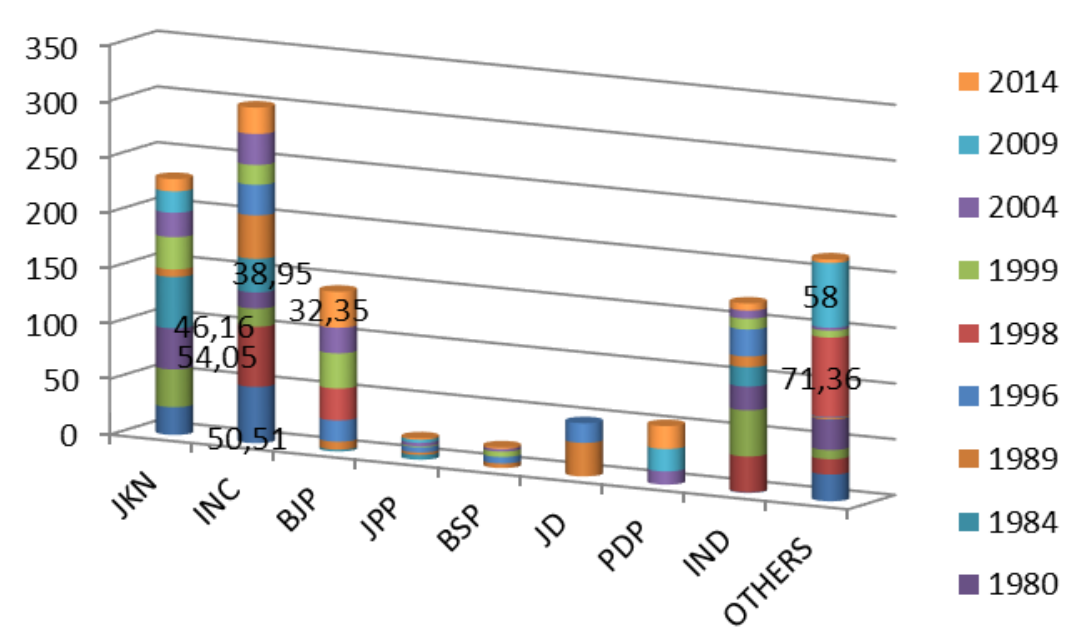

Figure 7 (Party wise distribution of the percentage of votes obtained by contesting parties in the state)

Public following of national conference among the masses of Jammu \& Kashmir can be gauged from the fact that till $1990 \mathrm{NC}$ on average bagged nearly 35\% vote share during general election, but post 1990, the vote share percentage of NC has declined considerably, and has come down to $17.5 \%$ during the last five general elections. This is also an indication of the fact that $\mathrm{NC}$ as a political party is no more popular among the masses of Jammu \& Kashmir in general and Kashmir 
in particular. BJP as a national level party has first time has managed to bag $32.35 \%$ vote share in 2014 general elections. Compared to Kashmir, the BJP enjoys public following more in Jammu \& Ladakh regions and the case is vice-versa for the PDP.

\section{SUMMARY OF FINDINGS \& DISCUSSION}

It is quite evident that the electorate of Jammu \& Kashmir actively participated in the each general election of the country and reaffirmed their faith and allegiance to Indian democratic setup as they moved from one general election to another. INC has been active in the state polity since 1967, while as Bhartiya Janta Party (BJP) and Bahujan Samaj Party (BSP) came to the scene since 1984 \& 1989 respectively. National Conference (NC) on the other hand is the only state level political party, which has been instrumental in the accession of Jammu \& Kashmir with the union of India.

After winning the 1998 assembly elections, Peoples Democratic Party (PDP) made a very profound impact on the state polity of Jammu \& Kashmir. PDP is also being seen as a dark horse \& a potential threat to the old political war horse of the state, the National Conference. The presence of PDP in the state polity can be gauged from the fact that, in 2014 assembly elections PDP emerged the single largest party by winning 28 seats out of 87 . The shift in the state polity can also be gauged from the fact that the BJP and the PDP, which used to consider each other as untouchables, given their ideological differences, have joined their hands and formed the govt., in the state, which political pundits also see as a victory of democracy and the respect of public mandate given these parties.

Despite surfacing of secessionist movement in the state in the year 1989-90 and is still around, $128 \%$ corresponding growth was recorded among the contestants during the 1998 general elections. Also, in the history of Jammu \& Kashmir a maximum 110 candidates participated in the general elections during the year 1996, the period when Kashmir valley was on boil with gun culture, social unrest was at its peak, law and order problem was around but masses showed their resolve and participated in the democratic process of the country, something unbelievable, which may not go well among the hardliners of Kashmir, but a harsh reality.

Role of Independent candidates in keeping the boat of democratic process afloat in the state, especially during the turmoil period cannot be overlooked. During the 1996 general elections over $76 \%$ candidates who contested in the elections were independents. By contesting general elections by this much number of candidates as independents at the height of social unrest shows that how far the people of Jammu \& Kashmir showed their faith in the democratic process of the country. By participating in elections, they not just defied the dictates of extremist groups, but also not bothered for their life. Apart from this on average 54\% candidates contesting in each general election in the state are independents.

The secessionists of Kashmir should take cue from the Scottish referendum, where the demand to secede from the United Kingdom was rejected by 55\% votes. The Scottish people preferred to continue their 300 year old association the UK. The secessionists of the Kashmir need to give a good thought over it as what made Scottish people to reject the freedom and chose to continue live as they are. Surely, such decisions are not taken on the basis of emotions but given the sensitivity of the issue, where larger interests get better protected. There is no second thought in that these are some of the prime considerations involved with the Scottish referendum. What is more important to see here is that referendum if even undertaken at some point of time will be easily defeated in the same way to that of Scottish one. Nearly $49 \%$ electorate of the state is from Jammu $\&$ Ladakh regions, who by no means support this secessionist movement and $51 \%$ is from Kashmir valley. Nearly $5 \%$ votes in Kashmir valley belong to religious minorities who by no means support this cause, while as about $10 \%$ electorate from the majority community of Kashmir belongs to ethnic minorities, who too are against this secessionist movement. So there is no point in exploring or exploiting those issues which by no means can work in favour of this unjustified secessionist struggle. 
Male dominance in the state polity gets reflected by the fact that during the entire electoral history of Jammu \& Kashmir only 5 women candidates could make to the parliament. The average corresponding growth of over $12 \%$ in the polling station during each election is quite noteworthy and is almost in proportion to the average $16.69 \%$ corresponding growth in the electorate from each general election.

Secessionist movement of the state doesn't enjoy the public support, especially when the questions are already being raised over the movement being supported by gun, hence purely a case of insurgency \& terrorism. By and large, the people of Jammu \& Kashmir are known for their simplicity, hospitality and fraternal love, but the sudden surge in the insurgency, not just created the law and order problems in the state, but also destabilized the social fabric of the state with wide spread bloodshed. More than seven lakh minorities, fearing for their lives were forced to abandon their homes, leaving behind everything and fled to other parts of the country. The secessionists of Kashmir are also being alleged of making selective killings with the motive to terrorize the minorities to flee them from the valley. Given the fact, the secessionist movement of the state doesn't have loci to stand on, which is being fought more on religious grounds and is not being supported by people from different walks \& faiths of life.

Besides, the unabated participation of people in the democratic process of the country by repeatedly defying the life threats and poll boycott calls is no way less than a referendum, whereby people of the state have repeatedly reaffirmed their faith in the democratic setup of the country.

\section{CONCLUSION}

Given the overwhelming public participation of Jammu \& Kashmir in the general elections of the country, be it before the eruption of social unrest in the valley, be it during the turmoil phase or even during the recovery phase, there is no let up in the enthusiasm of public participation in elections. The active participation of the public in the general elections of the country reflects one thing for sure that the people of the Jammu \& Kashmir believe in democratic values and have full faith in the democratic process of the country. This in itself corroborates the fact that the state of Jammu \& Kashmir is not devoid of democracy and the people of the state are not denied their fundamental rights as is being alleged by some sections of foreign media.

As for the question of secessionist movement of the Jammu \& Kashmir is concerned, it can be emphatically said that the movement does not enjoy the public support and is more a movement of armed struggle. The movement has almost been overthrown by the local populace, as these secessionist forces failed to keep the electorate of the state at bay even at gunpoint. One can emphatically say that the state of Jammu \& Kashmir is not devoid of democracy, there is no let up in the enthusiasm of people participating in democratic process of the country. Nearly $50 \%$ voter turnout was recorded in the 2014 general elections from the state, repeatedly corroborating that the people of state uphold the country's democratic setup supreme \& believe in the democratic values and participate in democratic exercise.

The provenance of Lincoln's famous phrase, "Govt of the people, by the people, for the people" is the only hymn, which can lead to global peace and prosperity and no region, nation or part of the world can remain elusive of it. The bottom line is, the Jammu \& Kashmir by all means appears to be an absolute federal constituent of the union of India and by no means is devoid of democracy.

\section{References}

[1] Azad, A.K. (1978): India Wins Freedom: An Autobiographical Narrative. Sangam Books.

[2] Desmond, E. (1995): The insurgency in Kashmir (1989-1991). Contemporary South Asia, 4(1), 5-16.

[3] Election Commissioner of India. (n.d). Retrieved August 11, 2014 from http://eci.gov.in/eci_main1/index.aspx 
[4] Ganguly, Š. (1996): Explaining the Kashmir insurgency: political mobilization and institutional decay. International Security, 21(2), 76-107.

[5] Ganguli, S. (2006): Will Kashmir stop India's rise?. Foreign Affairs, 45-56.

[6] Govt., of India, Ministry of Home Affairs (n.d). office of the Registrar General \& Census Commissioner India, census of India 2011, retrieved on September 01, 2014 from http://censusindia.gov.in/2011-Documents/Houselisting\%20English.pdf

[7] India.gov.in, National Portal of India (n.d). Govt., of India, states of India accessed on September 01, 2014 from http://india.gov.in/india-glance/states-india

[8] Instrument of Accession. (n.d). Instrument of accession executed by Maharaja Hari Singh on October 26, 1947. Retrieved on Dec 15, 2013 from http://www.kashmirinformation.com/LegalDocs/KashmirAccession.html

[9] Kohli, A. (1997): Can democracies accommodate ethnic nationalism? Rise and decline of self-determination movements in India. The Journal of Asian Studies, 56(02), 325-344.

[10] Kumar, A. (2003): State Electoral Politics: Looking for the Larger Picture. Economic and political weekly, 3145-3147.

[11] Pandita, R. (2014): Scenario of Public Participation in Assembly Elections of Jammu \& Kashmir: A Study (1962-2008). International Letters of Social and Humanistic Sciences, 16(1), 1-18

[12] Prime Ministers and Chief Ministers of Jammu and Kashmir since 1947. General Administration Department, Government of Jammu and Kashmir. Retrieved on 29 April 2014. Retrieved on September 01, 2014 from http://jkgad.nic.in/PDF/cmarchive.PDF

[13] Shastri, S. (2013): The 2013 Karnataka Assembly Outcome: Government Performance and Party Organization Matters. Studies in Indian Politics, 1(2), 135-152.

[14] Shaw-Albert, ed. (1901): The American Monthly Review of Reviews. Vol. XXIII, JanuaryJune 1901. New York: The Review of Reviews Company, p. 336

[15] Sikand, Y. (2002): The emergence and development of the Jama 'at-i-Islami of Jammu and Kashmir (1940s-1990). Modern Asian Studies, 36(03), 705-751.

[16] Tinker, I./Walker, M. (1956): The First General Elections in India and Indonesia. Far Eastern Survey, 25(7), 97-110.

[17] Tim-Haughton./Alenka-Kra_sovec. (2013): The 2011 parliamentary elections of Slovenia. Electoral Studies. 32, 201-204

[18] Tremblay, R.C. (1996): Nation, identity and the intervening role of the state: A study of the secessionist movement in Kashmir. Pacific Affairs, 471-497.

[19] Widmalm, S. (1997): The rise and fall of democracy in Jammu and Kashmir. Asian Survey, 1005-1030. 